\section{The blog as educational tool for health education: possibility of joint-service education}

\title{
Abstract
}

Introduction: the context of teaching practices, particularly in health, given the incorporation of technology resources, challenges teachers to adopt innovative educational strategies that promote interactivity, flexibility and autonomy. Information and communication technologies - ICT's, enable the creation of virtual learning environments, and the blog is a possibility to operationalize educational practices according to demands of the digital age.

Objective: to report and analyze the experience of building a blog as educational tool, applied to health education.

Method: This is an report of the experience of development of a formative teaching process in health, sought to exploit the teaching practices with the use of ICTss. The experiment involved teachers and students in a masters program, as well as users of a health service. The information gathered based on the records of this process by the students, on the presentation and evaluation of experience in classroom in 2015, presented through narrative.

Results: The process of construction and operation of the blog, as the ICT implementation strategy to health education, enabled the students responsible for the activity experience a process of meaningful learning, permeated by role and autonomy. In the perspective of joint education and health services, the blog has proved potent for the development of health education among the users.

Final thoughts: the blog has made it possible to develop the integration and collaboration between the subjects involved, as well as critical reflection about the educational tools in the field of health. In this way, ICT)s have proven powerful in developing an emancipating education and transformer of social reality.

Aretha Feitosa de Araújo1,2, José Maria Ximenes Guimarães ${ }^{1}$, Eduardo Carvalho de Souza ${ }^{1}$, Tatyane Oliveira Rebouças ${ }^{1}$, Heraldo Simões Ferreira1, Alice Maria Correia Pequeno', Antonio Germane Alves Pinto 1,2, Myrla Alves de Oliveira', Claudia Mendes Napoleão', Danilo Carvalho Rodrigues ${ }^{1}$, Ana Maria Araújo Salomão1, Élcio Basílio Pereira Machado 1,3

1 Curso de Mestrado Profissional Ensino na Saúde - CMEPES - Universidade Estadual do Ceará. Brazil.

2 Grupo de Pesquisa Clínica, Cuidado e Gestão em Saúde - GPCLIN da Universidade Regional do Cariri URCA. Brazil.

3 Instituto Federal do Maranhão - IFMA, Campus Caxias - MA . Brazil.

Contact information:

\section{Aretha Feitosa de Araújo}

”aretha.feitosa@gmail.com

\section{Keywords}

Health; Educational

Technology; Teaching, Blog,

Health Educational 


\section{Introduction}

The setting of the teaching practices, particularly in the field of health, is marked today by the insertion of technological resources in the academic world. Technological innovation has allowed the faster access to information and scientific knowledge, as well as greater interactivity between people in virtual environments, mediated by information and communication technologies - ICT's based on internet ${ }^{17,18}$.

In this context, the teacher is challenged to adopt educational strategies which make it possible to overcome the barriers of time-space, in which the student is treated in a more flexible way, and not linear and transdisciplinary. It is necessary to recognize the students as subject inserted in a world that offers them a variety of technologies that are well assimilated by him, which enable greater interaction in the search for knowledge, more participative and cooperative, encouraging the construction of autonomy and responsibility in the teaching-learning process ${ }^{1}$.

It is recognized that ICT's can be used as an educational resource, especially those developed on the internet, by allowing the interaction in distance education, which can be executed through several strategies, including: virtual learning environments, blogs. Thus, they enable the search, systematization and even the dissemination of content, stimulating the operationalization of significant learning practices. Therefore, ICT mediated education practices empower the development of critical thinking, reflection and action-oriented understanding of reality, overcoming the mere reproduction of knowledge.

Throughout the ages, many knowledge, technologies and scientific trials have contributed significantly in the area of health, in the expansion of the potential diagnosis of pathologies, in improving the quality of life of the population and in the permanent education of health care professionals. With the advance of information technology, new technologies have emerged in facilitating people's access to sources of information, making these reaching users in real time. There is a necessity for health education, to understand the importance of information technology, once that science has become an important technological tool at the disposal of the man².

So, promoting changes in pedagogical practice of teachers in health education institutions is appropriate on such technological reality. Teachers, in turn, by using ICT and stimulating the use of proposed activities to the student, provide new discoveries and creative actions to act in the digital age. In this regard, Freire says that critical reflection on practice becomes a theory/practical relationship and that teaching is not to transmit knowledge, but to create the possibility of building it ${ }^{3}$.

The students, front of these pedagogical tools, particularly in health education, often see themselves challenged to use them in their professional activities as a possibility to enlarge the practices of care and health education by the population. Furthermore, its use has the potential to promote a better understanding of the social reality in which they are inserted. This health education institutions, however, introduce changes in their didactic-pedagogical practices mediated by ICT's, promoting a learning emancipatory process to the society, with attention in the Brazilian health needs ${ }^{4}$.

Nevertheless, is evident the need for qualified health professionals to act as teachers, i.e. order pedagogical training with a view to improving teaching practices in health. Based on this understanding, higher education institutions have been encouraged to develop formative processes in this area. Thus, the State University of Ceará, Brazil, deployed the professional master's course education in health, which promotes the development of innovative pedagogical practices aiming at the transformation in teaching practices as health care. To this end, includes in its curriculum to discipline called Information and Communication Technolo- 
gies Applied to Education in Health. In this, ICT is applied, specifically the blog, on teacher education as a strategy of joint education and health services.

The blog as educational tool can be defined as an individual or collective electronic space that enables the sharing of information, ideas, opinions, materials and references. It is configured, therefore, as a virtual environment for the reading and production of short texts that can be communicated, questioned and commented on by other readers. Such genre can be used by students or teachers, to work various types of content, from different disciplines, at any level of education, including in graduate school ${ }^{5}$.

The Blog is a virtual tool can be maintained on the internet by various authors and enabling communication between visitors. The authors/administrators of the blog can feed him through texts, photos, illustrations, cartoons, videos and links as need for pedagogical information.

In fact, the blog is a tool that can help students and teachers in health on exposure of their knowledge to the public. That characterizes changes in health education scenario where enables a close relationship teaching-health service, leading the student to meaningful learning, where these through such technological tools can manipulate their own representations of knowledge ${ }^{3}$.

In the face of an educational context, the teacher-student-community relationship, mediated by ICT's, creates an expectation of knowledge construction when direct relations are not possible in the daily, the blog tool enables dialogue asynchronously where users do not need while being connected to the communication between them. In this way the use of technological tools is of extreme importance in the modern world, since people do not provide enough time for training activities and information6.

On the understanding that the blog is a important educational tool in health education, the objective of this study is to report and analyze the experience of building a blog as educational tool applied to health education.

\section{Methods}

This study deals with a descriptive account of the type of experience applied in a training process in health during the course of the discipline of Educational Technology in Health offered in the professional master's program in Health Education from the State University of Ceará- UECE. The training process during the course aimed to equip teaching practices using ICT. Therefore, we adopt here the narrative, whose information was gathered from the records of this process by students, presentation and evaluation of the experiment in the classroom in 2015.

The subjects are students of the MA program , which narrate the health education of driving experience by creating a blog. The group of students created the blog and technology applied to high school students in health and community with ties in the area of health during the period from August to September 2015. The disclosure form and unit of choice for the dissemination and application of the blog were students of a public school in the state of the nursing course of Ceará and people linked to the area of health in general. The study followed the ethical precepts of research based on Resolution 466/12.

It is understood that the narrative is a methodological strategy that allows you to express a time and circumstance. Thus, it is considered that, initially, the narrative is used to report events and situations, one can get various interpretations, however, the constituent dimensions of the problems thought always stand at the core of the report, which shows flexibility in its construction. In addition, the collaborative production strategy of the account can add other elements that allow the subject to recounts being involved in the action, understand the movement and interpret reality ${ }^{2}$. The narrative allows therefore the systematization of experiences and is organized in a sequential trajectory, with a beginning, middle and end 7,8 . 
The experience here reported and analyzed began with the proposal to set up a blog, as an integral activity of the discipline of Information and Communication Technologies applied to education on health, whose purpose was, besides stimulating the use of ICT's in teaching practice in health. The action was developed during implementation of the discipline of information and Communication Technologies applied to education in health, in terms of articulation between education and services in the framework of the master's program in Health Education Professional, State University of Ceará. To achieve this, students should form groups of up to four participants who should choose a subject linked to a service in which they were entered, to promote the construction and discussion on the blog, directed to the public service, which could students or health service users, depending on the selected scenario.

In these terms, the perception of the students of the master in relative need for awareness of health students, health professionals and community about the blood drive, allowed the election of the educational proposal on the donation of blood along the center of Haematology and haemotherapy. Thus, the opportunity arose to contribute to the development and dissemination of the national policy of blood and blood products, adopted by the Ministry of health, as well as to disseminate the idea of social responsibility is the voluntary donation of blood. The target audience to be reached by the blog was represented by students from several courses of the health area, health professionals and the Blood and the community.

The blog was titled «life beats» and the choice of theme was agreed between the students of the group. The main focus of the blog was the stimulus to blood donation and the discussion of topics related to hematology. The blog domain chosen was blogpost, which is available for free. After the creation of the domain, the Group began to select the tools that would be used, as well as the strategies to achieve the objectives proposed by the activity, thus setting the layout of the blog.

The activity proposed by the discipline had some requirements to be covered. The blog had to follow a structure to its functionality. To this end, should have different sections, with polls for the interaction with the public, videos, cartoons, scientific articles and posts as shown in Figure 1.

Figure 1: Structure of formation of the Blog.

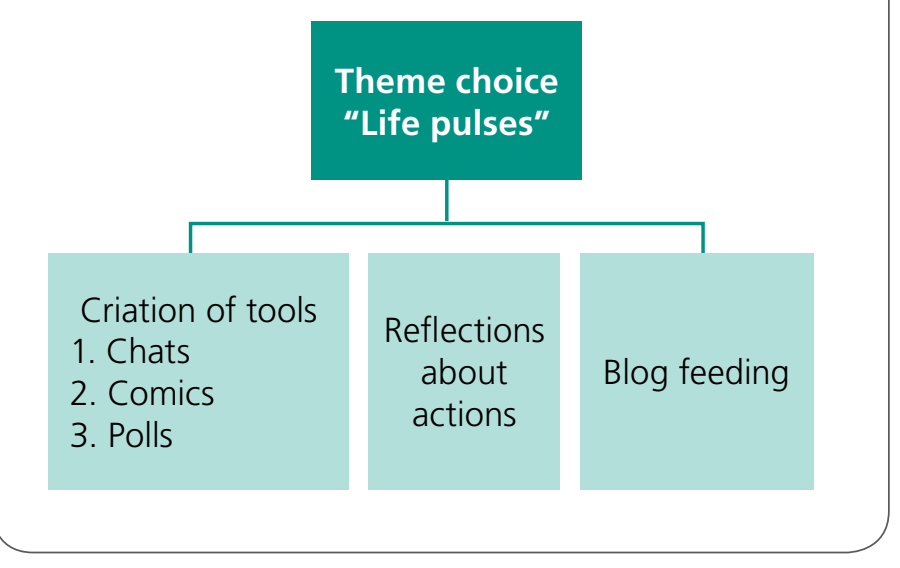

In this way, the blog was updated weekly, by the members of the team, following the established structure of construction and updating.

\section{Results and discussion}

The records gathered disclosed the significant importance of the proposal of providing students with ICT's for the development of formative processes in health. The analysis allowed to organize records in thematic axes, as shown below.

\section{The blog as a tool for meaningful learning}

The experience of creating a blog has been challenging, considering the complexity of choice and selection of the material, because they should be inviting, simple, let visitors curious about blood donation and about contributing in some way to a critical sense capable of generating thoughts in blog users about their actions, from the time 
itıs taken to make choices and make public their opinion assisting in the process of reflection and knowledge construction enables a critical thinking about the phenomenon in question.

The teaching-learning strategy using the Blog as a methodological resource proved to be very effective in this study. The authors were involved with the study proposal seeking improvement of their knowledge, both front of information and communication technologies and the contribution of the proposed theme content.

The blog also fostered interaction and collaboration, creating the possibility of developing the role of the teacher as mediator in the production of knowledge, since he has an active role to instigate discussion through comments, leveraging the interaction between the class; encourage collaborative writing, responsibility, critical thinking, and argumentative ability; encourage extra-curricular learning so playful; develop the ability to search and select information ${ }^{5}$.

Thus, the challenge of the construction process of the blog has provided the possibility of selecting the contents that would be needed to learning autonomously, creative and with flexibility of space time in the production of the material prepared by the group, which converges to the principles of distance education and learning.

"We had a huge challenge, but it was very interesting to build a free, select the material used. Sometimes we doubt whether that material met the need, then discussed and we decided collectively and learned a lot". (Student 2)

"The way to learn in this study was very motivating, information and communication technologies are in full swing in health education is necessary for us to future teachers in health education have the mastery of these pedagogical tools". (Student 3)
"Learning new educational technologies is very rich, nowadays we deal with an emancipatory education and asset-based methods". (Student 7)

With regard to significant learning, blogs may provide an opportunity of construction of knowledge with a lot of autonomy, as well as those who access it. Posts are expressed by the knowledge that they will acquire and open the opportunity for discussion among educators and students ${ }^{9}$. The blog is still an informal and formal communication channel between the educators and students by promoting social interaction. For students, the blog is a way for the exercise of their own learning, enables easy implementation tool allowing frequent updates and the insertion of comments from your visitors ${ }^{10}$.

\section{The blog as a tool for health education}

Thought initially as a pedagogical strategy discipline on teacher education in master course, the blog LIFE PULSES was set up as a powerful place for the development of health education for the public user of the Hematology and Hemotherapy Center of Ceará.

Updating content on blog, held by the team, routinely allowed more dynamism approaching the virtual environment with the reality of the community, in which if realized through his answers in the forums and chat rooms, many questions and concerns regarding the donation of blood. The perception, on the part of the team, that files and documents were accessed and commented on by the community, corroborated to consolidate the understanding that in addition to bringing people together, allow the discussion of content, facilitate the construction of knowledge, the blog of configures how effective space for practice of health education. Based on this finding, currently the graduate student team member who plays in that service continues up- 
dating and weaving discussions in response to the comments of those who access the tool.

Thus, the blog takes a prominent position in the educational context, given their pedagogical purpose. Barbosa and Granado' corroborated with that statement to ponder that «If there is any area where the blogs can be used as tools of communication and exchange of experience with excellent results, this area is without doubt the education». This exchange of experience has the potential to foster learning in a context of collaboration, as proves the research carried out by Carmo and Pontes ${ }^{6}$. The authors highlight that the Blog represents a rich space of interaction among students. The blog is a tool where participants are authors and producers of knowledge. Autonomy and freedom are protagonists of this process that breaks the traditional model of "acquiring knowledge"14.

Is in the interaction with the community that we realize that the blog can expand its role as an educational tool in the teaching learning process to be used as a technology for the development of education in health, this is understood as a political process of training for active citizenship, to transformative action of social reality and the pursuit of improved quality of life $\mathrm{e}^{12}$.

In this perspective the blog had the opportunity to promote awareness about the importance of blood donation and, through interaction, enable critical reflection of the subject about their social reality. This tool also enabled the stimulation of self-care related health conditions necessary to conduct blood donation. The blog as a tool for health education with a individual and collective view can act also in promoting health, in so far as beddybye for the transformation of reality with decisionmaking, building autonomy of the subject in the care practice in favor of the improvement of living and health 3,16 .

It should be noted that, in 15 days, the blog had 372 visitors access. Obtained the poll link that asked if the visitor had already conducted blood dona- tion. It should be noted that of the 87 people who responded, 59 stated that have already performed blood donation, but 28 never donated. The comments of the posts were directed to an intervention and practice of health education, because it showed a lot of questions and curiosities about the blood drive, myths and taboos. It was an opportunity for clarification and of making explicit the importance of the involvement of society in promoting the blood drive, through the video posted on the blog, titled: Turma da Mônica e a doação de sangue.

An article chosen for making available on the blog was about the acceptability of blood donors in the Northeastern Brazilian public blood bank was blood donors 'satisfaction' on the service, the choice of the article was due to the results of the aforementioned video post, as a way to encourage and invite visitors to meet the blood donation. Expressed through the lines, we see the motivation of students for the proposed activity .

We " When I saw that amount of hits, I was very happy because I realized that blogging as a teaching tool is very efizaz". (Student 1)

"The way that disclosed and access of school students and the local community, only proved that the blog is kind of very good communication for health education". (Student 4)

"The participation and commitment of the people on the platform, only shows that it is worth exploring these educational technologies in health education". (7 student)

After the analysis of posts, we find that the educational opportunities in health of the blog achieved exquisite and surprising progress, encouraging visitors to interact and clarify questions about the donation of blood by using the network as a pedagogical tool, as well as the promotion of 
meaningful learning, through health education in virtual space ${ }^{19}$.

These contributions of virtual media in health education occur because it is believed that the learning collaborative, mediated by these technologies, provide a new vision and perception of reality glimpsing possibilities offered by contemporary challenges capable of fostering the acquisition of diversified knowledge $\mathrm{in}^{13-15}$

\section{Final considerations}

The case studies have in nature, a great opportunity to contribute to the production and dissemination of scientific knowledge, Rico of senses and meanings in the world of science, by expressing through their authors what an activity performed may allow seizure of a social phenomenon with theoretical and practical developments. Thus, the case studies is built based on observation and in relationship with the resulting empirical common sense, based on the experience of that group or person, increasing the development of new theoretical synthesis.

When reporting how the use of a blog as an educational tool to promote joint teaching and service, it was possible to notice that this information and communication technology when applied to health education, encourage the development of meaningful learning in the student/participant, because it stimulates the build your own knowledge in the process of operationalization of pedagogical action proposal. Furthermore, when you direct the contents of the blog to a target audience, composed by users of a specific health service, in case the center of Haematology and haemotherapy in Ceará, showed the potential of this tool as a strategy for health education. In these terms, develops the understanding that should encourage the adoption of these technological resources, in order to make them present in the teaching practices in health, both the Faculty and the students, considering the potential shown in this study.
You may want to emphasize here the potential use of the Blog "life Beats" in health education. At first, allowed teachers reflect on the possibilities of use of strategies for building ICT-mediated educational practices for students; the second moment, the challenges posed to students regarding the development experience of the blog, the first contact with this strategy. As well, some did not possess skills needed to develop the task, which were developed in the process from decision-making in relation to the theme, to content, to the opening and operation of the virtual space of interaction and communication named blog; Finally, the relevance to the academic community and also to health professionals, to build knowledge through innovative practices, which allow meaningful learning. Thus, the insertion in the culture of use of chat rooms, blog posts and discussion in health at blog, showed up as positive strategy on teacher education of health professionals who act both in educational institutions and health services that develop health education by the population.

In this study, developed the integration and collaboration between the subjects involved in the process of building the Blog, as well as production of pedagogical material, videos and image, system update, interact in chat rooms and disclosure in social networks. This kind of experience comes allowing more and more reflection about the use of educational technologies in health as a means of learning in any time and space in the life of the individual.

Finally, showed that use of ICT's makes an emancipating education and transformer compared to a traditional teaching, because the role of the user/ student front of this process is a subject and active in the construction of learning. When we use a blog as a learning tool for our pedagogical practice, are consistent with the professional profile of the $21^{\text {st }}$ century, where innovation and technology go together. 


\section{References}

1. Matos, P N, Gonçalves ED, Maia RCC. Utilização das Tecnologias da Informação e Comunicação (TICS) por professores de ciências ao ensinar energia. Revista Tecnologias na Educação. 2015; 7 (13): 1-12.

2. Oliveira, R. M. C. de. Interfaces colaborativas e Educação: o uso do blog como potencializador do processo de avaliação. In: Dias, Paulo; Osório, António José. (Org.). Ambientes educativos emergentes. 1 ed. Braga: Universidade do Minho - Centro de Competência, 2008.

3. Buss, M. P. Uma Introdução ao Conceito de Promoção da Saúde. In: Czeresnia, D.; Freitas, C. M. de. Promoção da Saúde: Conceitos, Reflexões, Tendências. Rio de Janeiro: Editora Fiocruz, 2009 .

4. Araújo, AF; Oliveira, MA; AbreU, JV; Souza, EC; Pequeno, AMC; Gomes, AMA; Machado, MFAS; Rodrigues, DC; Rebouças, TO; Napoleão, CM; Salomão AMA, Bruno, G; Guimarães, JMX. Active Methods of Teaching-Learning in the Health Area: the Problems in Nursing Education. Medical Society. International Archives of Medicine. 2015; 9 (5): 1-7.

5. Carvalho, AAA. Blogue: uma ferramenta com potencialidades pedagógicas em diferentes níveis de ensino. In: Colóquio sobre questões curriculares, Braga,Portugal, 2006.

6. Gomes, Maria João; LOPES, António Marcelino. Blogs escolares: quando, como e porquê? Disponível em https:// repositorium. sdum.uminho.pt/bitstream/ 1822/6487/1/gomes2007.pdf. Acesso em: 05 de abril. 2016

7. Holliday, O.J. Para sistematizar experiências. João Pessoa: Ed Universitária;1996.

8. TAMAR, L. Blogs pedagógicos em saúde: possibilidades de interação por meio da escrita coletiva de hipertextos cooperativos. Revista Latinoamericana de Tecnologia Educativa - RELATEC, 8 (2), 91-108. Disponível em: . Acesso em: 08 de abril de 2016

9. BARBOSA, A.; GRANDAD. E.R. WeBlog, Diário de Bordo. Porto Editora, Porto, 2004.

10. Carmo; R. L. J. Pontes. Collaborative learning concept implementation through Web.2.0tools: the case of industrial engineering fundamentals' discipline. International Journal of Engineering Education, v. 29: 205-214, 2013.

11. Staa, B. V. Sete motivos para um professor criar um blog, 2005. Disponível em: <http://www.educacionalpositivo.com. br/articulistas/betina_bd.asp?codtexto=636> Acesso em: 06 de abril de 2016

12. Freire, P.R.N. Pedagogia da Autonomia - Saberes necessários à prática educativa. São Paulo, Brasil: Paz e Terra : Coleção. Leitura, 1997

13. Arrais, P.s.d.; Aguiar, A.s.w.; Souza, M.a.n.; Machado, M.m.t.; Mota, M.v.; Alves, R.s.; Araujo, M.f.m. Integralidade: Desafio Pedagógico do PET-Saúde /UFC. Revista brasileira de educação médica. 36 (1, Supl. 2) : 56-61; 2012.
14. Pelicioni, M.C. F; Pelicioni, A.F. Educação e promoção da saúde: uma retrospectiva histórica. O mundo da saúde. São Paulo: 2007: jul/set 31(3):320-328. Disponível: http://www.saocamilosp.br/ pdf/mundo_saude/55/02_restrospectiva_historica.pdf. Acesso em: 03/04/2016

15. Dupret, L.m; Mirian, M.m. aConcepções de Currículo, Saúde e Tecnologia de Professores do Ensino Fundamental e sua Influência nas Práticas Educativas. RECIIS (Online); 9(4): 1-10, out.-dez.2015.

16. Pereira, T.a; Areco, K.s.n; Tarcia, R.m. Lino, S.D. Uso das Tecnologias de Informação e Comunicação por Professores da Área da Saúde da Universidade Federal de São Paulo. Rev. bras. educ. méd; 40(1): 59-66, jan.-mar. 2016.

17. Silva, A.n; Santos, A.M.g; Cortez, E.A. Limites e possibilidades do ensino à distância (EaD) na educação permanente em saúde: revisão integrativa. Ciênc. saúde coletiva; 20(4): 1099-1107, 04/2015.

18. Brutscher, V.j.; Sampaio, J.P; Potencialidades da educação a distância: modalidades em consolidação. Rev. bras. ciênc. saúde; 16(03)out. 2012.

19. Trindade, $M, A, B$. As tecnologias da informação e comunicação (TIC) no desenvolviemnto de profissionais do Sistema Único de Saúde (SUS). São Paulo; Instituto de Saúde; 2011. 264 p.

Publish in International Archives of Medicine

International Archives of Medicine is an open access journal publishing articles encompassing all aspects of medical science and clinical practice. IAM is considered a megajournal with independent sections on all areas of medicine. IAM is a really international journal with authors and board members from all around the world. The journal is widely indexed and classified Q2 in category Medicine. 